Nur, et al/Jurnal Ekonomi Syariah Teori dan Terapan Vol. 6 No. 1 Januari 2019: 97-113; DETERMINAN RETURN ON ASSET (ROA) PADA INDUSTRI PERBANKAN SYARIAH DI INDONESIA PERIODE 2010-2018: PENDEKATAN AUTOREGRESSIVE DISTRIBUTED LAG (ARDL)

\title{
DETERMINAN RETURN ON ASSET (ROA) PADA INDUSTRI PERBANKAN SYARIAH DI INDONESIA PERIODE 2010-2018: PENDEKATAN AUTOREGRESSIVE DISTRIBUTED LAG (ARDL)
}

\author{
Feranti Farah Nur \\ Departemen Ekonomi Syariah- Fakultas Ekonomi dan Bisnis-Universitas Airlangga \\ Email: feranti-f-n-11@feb.unair.ac.id \\ Raditya Sukmana \\ Departemen Ekonomi Syariah- Fakultas Ekonomi dan Bisnis-Universitas Airlangga \\ Email: raditya-s@feb.unair.ac.id
}

\begin{abstract}
:
This research aimed to test and analyze the influences of Non-Performing Financing (NPF), Capital Adequacy Ratio (CAR), and Operational Cost of Operational Income (BOPO) on Return on Asset (ROA) in Indonesian Sharia Banking Industry for period 2010-2018. It used a quantitative approach. Furthermore, the data analysis technique used was Autoregressive Distributed Lag (ARDL). The results of this research showed that in the long-term, NPF and $B O P O$ variables had a negative and significant effect on the variable of Return on Asset (ROA), and the variable of CAR had a positive and insignificant effect on the variable of Return on Asset (ROA). Meanwhile, in the short-term, NPF and BOPO variables had a negative and significant effect on the variable of Return on Asset (ROA), and the variable of CAR had a positive and significant effect on the variable of Return on Asset (ROA).

Keywords: Islamic Banks, Return on Asset, Non Performing Financing, Capital Adequacy Ratio, Operational Cost of Operational Income, Autoregressive Distributed Lag.
\end{abstract}

\section{PENDAHULUAN}

\section{Latar Belakang}

Bank syariah adalah bank yang aktivitasnya meninggalkan masalah riba. Penghindaran bunga yang dianggap sebagai riba merupakan salah satu tantangan yang harus dihadapi oleh bank syariah. Para ekonom Muslim telah berusaha untuk menemukan cara yang tepat dalam menggantikan sistem bunga (riba) dalam transaksi perbankan dan keuangan Islam. Upaya yang dilakukan oleh para ekonom Muslim ini bertujuan untuk membangun teori ekonomi yang bebas bunga (riba). Oleh karena itu, mekanisme perbankan syariah adalah melakukan kegiatan usaha dengan tidak menggunakan prinsip bunga (riba) melainkan dengan menggunakan prinsip bagi hasil. Hal ini dikarenakan alasan berdirinya bank syariah adalah dilarangnya penggunaan riba dalam transaksi keuangan maupun non keuangan. Dalam sistem bunga, bank tidak akan tertarik dalam kemitraan usaha kecuali apabila ada jaminan kepastian pengembalian modal dan pendapatan bunga (Arifin, 2002:39).

Karakteristik sistem perbankan syariah yang beroperasi berdasarkan prinsip bagi hasil memberikan alternatif sistem perbankan yang saling menguntungkan bagi masyarakat dan bank serta menonjolkan aspek keadilan dalam bertransaksi, investasi yang beretika, mengedepankan nilai-nilai kebersamaan dan persaudaraan dalam berproduksi, dan menghindari kegiatan

1) Jurnal ini merupakan bagian dari Skripsi Feranti Farah Nur, NIM: 041114145, yang diuji pada tanggal 24 Juli 2018 
Nur, et al/Jurnal Ekonomi Syariah Teori dan Terapan Vol. 6 No. 1 Januari 2019: 97-113; DETERMINAN RETURN ON ASSET (ROA) PADA INDUSTRI PERBANKAN SYARIAH DI INDONESIA PERIODE 2010-2018: PENDEKATAN AUTOREGRESSIVE DISTRIBUTED LAG (ARDL)

spekulatif dalam bertransaksi keuangan. Dengan menyediakan beragam produk serta layanan jasa perbankan yang beragam dengan skema keuangan yang lebih bervariatif, perbankan syariah menjadi alternatif sistem perbankan yang kredibel dan dapat dinikmati oleh seluruh golongan masyarakat Indonesia tanpa terkecuali (www.bi.go.id).

Untuk memelihara kepercayaan masyarakat, perbankan syariah diwajibkan untuk menjaga tingkat kesehatannya. Kewajiban perbankan syariah untuk menjaga tingkat kesehatannya ditentukan dalam UndangUndang No. 21 Tahun 2008 pasal 51 ayat 1 yang menjelaskan bahwa bank syariah dan UUS wajib memelihara tingkat kesehatan yang meliputi sekurangkurangnya mengenai kecukupan modal, kualitas aset, likuiditas, rentabilitas, solvabilitas, kualitas manajemen yang menggambarkan kapabilitas dalam aspek keuangan, kepatuhan terhadap prinsip syariah dan prinsip manajemen Islami serta aspek lainnya yang berhubungan dengan usaha bank syariah dan UUS (Usman, 2012:144).

Salah satu indikator yang dapat digunakan untuk mengukur tingkat kesehatan dari perbankan syariah adalah rasio rentabilitas atau dapat disebut juga dengan rasio profitabilitas. Menurut Kasmir (2013:196), Rasio profitabilitas merupakan rasio untuk menilai kemampuan perusahaan dalam mencari keuntungan. Rasio ini juga bertujuan untuk memberikan ukuran tingkat efektivitas manajemen suatu perusahaan. Hal ini ditunjukkan oleh laba yang dihasilkan dari penjualan dan pendapatan investasi. Kemudian hasil pengukuran tersebut dapat dijadikan sebagai alat evaluasi kinerja manajemen selama ini, apakah perusahaan telah bekerja secara efektif atau tidak. Salah satu dari jenis rasio profitabilitas yang dapat digunakan adalah rasio Return on Asset (ROA).

Ketatnya persaingan antar bank syariah secara langsung maupun tidak langsung berpengaruh terhadap kenaikan atau penurunan rasio Return on Asset (ROA). Persaingan antar bank syariah menyebabkan bank syariah dituntut untuk memiliki tingkat kesehatan yang baik, salah satunya adalah memiliki tingkat keuntungan (laba) yang tinggi. Pencapaian tingkat keuntungan (laba) yang tinggi bagi bank syariah dapat dipengaruhi oleh beberapa faktor.

Menurut Haron (2004), tingkat profitabilitas atau dapat diukur dengan rasio Return on Asset (ROA) dapat dipengaruhi oleh rasio kinerja keuangan bank syariah. Ramlall (2009) juga menyatakan bahwa salah satu faktor yang dapat mempengaruhi tingkat profitabilitas bank syariah adalah karakter spesifik bank (bank specific characteristics) yang meliputi berbagai indikator kinerja keuangan bank syariah seperti risiko kredit, modal dan efisiensi. Risiko kredit/pembiayaan dapat diproksikan dengan rasio Non Performing Financing (NPF), modal dapat diproksikan dengan rasio Capital Adequacy Ratio 
Nur, et al/Jurnal Ekonomi Syariah Teori dan Terapan Vol. 6 No. 1 Januari 2019: 97-113; DETERMINAN RETURN ON ASSET (ROA) PADA INDUSTRI PERBANKAN SYARIAH DI INDONESIA PERIODE 2010-2018: PENDEKATAN AUTOREGRESSIVE DISTRIBUTED LAG (ARDL)

(CAR) dan efisiensi dapat diproksikan dengan rasio Biaya Operasional Pendapatan Operasional (BOPO).

Secara umum variabel kinerja kevangan adalah variabel yang sering digunakan dalam penelitian. Akan tetapi dalam penelitian-penelitian sebelumnya, tidak ada yang menggunakan teknik analisis data dengan metode Autoregressive Distributed Lag (ARDL) dimana metode ARDL adalah metode analisis data yang bertujuan untuk menguji pengaruh jangka panjang dan jangka pendek antara variabel dependen dengan variabel independen. Oleh karena itu, penulis merasa perlu untuk mencari tahu lebih lanjut tentang seberapa besar pengaruh variabel kinerja keuangan bank syariah yaitu Non Performing Financing (NPF), Capital Adequacy Ratio (CAR) dan Biaya Operasional Pendapatan Operasional (BOPO) terhadap Return on Asset (ROA) industri perbankan syariah di Indonesia dengan menggunakan metode Autoregressive Distributed Lag (ARDL).

\section{Rumusan Masalah}

Berdasarkan uraian latar belakang diatas, maka rumusan masalah yang dapat diajukan pada penelitian ini adalah:

1. Apakah variabel Non Performing Financing (NPF) memiliki pengaruh jangka panjang dan jangka pendek terhadap variabel Return on Asset (ROA) industri perbankan syariah di Indonesia periode 2010 2018 ?
2. Apakah variabel Capital Adequacy Ratio (CAR) memiliki pengaruh jangka panjang dan jangka pendek terhadap variabel Return on Asset (ROA) industri perbankan syariah di Indonesia periode 2010 - 2018?

3. Apakah variabel Biaya Operasional Pendapatan Operasional (BOPO) memiliki pengaruh jangka panjang dan jangka pendek terhadap variabel Return on Asset (ROA) industri perbankan syariah di Indonesia periode 2010 - 2018?

\section{Tujuan Penelitian}

Penelitian ini bertujuan untuk menjawab rumusan masalah, yaitu :

1. Untuk menguji dan menganalisis pengaruh jangka panjang dan jangka pendek antara variabel Non Performing Financing (NPF) dengan variabel Return on Asset (ROA) industri perbankan syariah di Indonesia periode 2010 - 2018.

2. Untuk menguji dan menganalisis pengaruh jangka panjang dan jangka pendek antara variabel Capital Adequacy Ratio (CAR) dengan variabel Return on Asset (ROA) industri perbankan syariah di Indonesia periode 2010 - 2018.

3. Untuk menguji dan menganalisis pengaruh jangka panjang dan jangka pendek antara variabel Biaya Operasional Pendapatan Operasional (BOPO) dengan variabel Return on Asset (ROA) 
Nur, et al/Jurnal Ekonomi Syariah Teori dan Terapan Vol. 6 No. 1 Januari 2019: 97-113; DETERMINAN RETURN ON ASSET (ROA) PADA INDUSTRI PERBANKAN SYARIAH DI INDONESIA PERIODE 2010-2018: PENDEKATAN AUTOREGRESSIVE DISTRIBUTED LAG (ARDL)

industri perbankan syariah di Indonesia periode 2010 - 2018.

\section{LANDASAN PUSTAKA}

\section{Bank Syariah}

Bank syariah adalah bank yang beroperasi dengan tidak mengandalkan pada bunga. Bank Islam atau dapat disebut juga dengan bank tanpa bunga adalah lembaga keuangan perbankan yang operasional dan produknya dikembangkan berlandaskan pada Al Quran dan Hadist Nabi Muhammad SAW. Dengan kata lain, bank Islam adalah lembaga keuangan yang usaha pokoknya memberikan pembiayaan dan jasa-jasa lainnya dalam lalu lintas pembayaran serta peredaran vang yang pengoperasiannya disesuaikan dengan prinsip syariah Islam (Muhamad, 2002:13).

Sedangkan pengertian perbankan syariah menurut Ismail (2011:32) adalah segala sesuatu yang menyangkut tentang bank syariah dan unit usaha syariah yang mencakup kelembagaan, kegiatan usaha serta cara dan proses dalam melaksanakan kegiatan usahanya. Bank syariah memiliki fungsi menghimpun dana dari masyarakat dalam bentuk titipan dan investasi dari pihak pemilik dana. Fungsi lainnya adalah menyalurkan dana kepada pihak lain yang membutuhkan dana dalam bentuk jual beli maupun kerja sama usaha.

Ismail (2011:32) juga menyatakan bahwa bank syariah merupakan bank yang kegiatannya mengacu pada hukum Islam dan dalam kegiatannya tidak membebankan bunga maupun tidak membayar bunga kepada nasabah. Imbalan yang diterima oleh bank syariah maupun yang dibayarkan kepada nasabah tergantung dari akad dan perjanjian antara nasabah dan bank. Perjanjian (akad) yang terdapat di bank syariah harus mematuhi syarat dan rukun akad sebagaimana diatur dalam syariah Islam.

\section{Return On Asset (ROA)}

Rasio Return on Asset (ROA)

merupakan rasio digunakan untuk mengukur kemampuan manajemen bank dalam memperoleh keuntungan (laba) secara keseluruhan. Semakin besar ROA suatu bank, semakin besar pula tingkat keuntungan yang dicapai bank tersebut dan semakin baik pula posisi bank tersebut dari segi penggunaan aset (Dendawijaya, 2003:120). Sedangkan menurut Kasmir (2013:201), Return on Asset (ROA) merupakan rasio yang menunjukkan hasil (return) atas jumlah aktiva yang digunakan dalam perusahaan. Return on Asset juga merupakan suatu ukuran tentang efektivitas manajemen dalam mengelola investasinya. Hasil pengembalian investasi menunjukkan produktivitas dari seluruh dana perusahaan, baik modal pinjaman maupun modal sendiri. Semakin rendah rasio ini maka semakin kurang baik, begitupun sebaliknya.

\section{Non Performing Financing (NPF)}

Iswi dalam Umam (2016:206) menyatakan bahwa kredit bermasalah (NPL) atau dalam bank syariah disebut pembiayaan bermasalah (NPF) selalu 
Nur, et al/Jurnal Ekonomi Syariah Teori dan Terapan Vol. 6 No. 1 Januari 2019: 97-113; DETERMINAN RETURN ON ASSET (ROA) PADA INDUSTRI PERBANKAN SYARIAH DI INDONESIA PERIODE 2010-2018: PENDEKATAN AUTOREGRESSIVE DISTRIBUTED LAG (ARDL)

diawali dengan terjadinya wanprestasi (ingkar janji) yaitu suatu keadaan dimana debitur tidak mampu memenuhi janjijanjinya sebagaimana tertera dalam perjanjian kredit (termasuk perjanjian pembiayaan). Penyebab debitur melakukan wanprestasi dapat bersifat alami (di luar kemampuan debitur) maupun karena iktikad tidak baik yang dilakukan oleh debitur. Sedangkan Umam (2016:206) menjelaskan bahwa kredit bermasalah adalah kredit yang di dalam pelaksanaannya belum memenuhi target yang diinginkan oleh bank dan memungkinkan timbulnya risiko di kemudian hari bagi bank. Penyelamatan kredit bank dapat dilakukan dengan cara penjadwalan kembali (rescheduling), persyaratan kembali (reconditioning) dan penataan kembali (restructuring).

\section{Capital Adequacy Ratio (CAR)}

$$
\text { Denda wijaya }
$$

menyatakan bahwa CAR adalah rasio yang memperlihatkan seberapa jauh seluruh aktiva bank yang mengandung risiko (kredit, penyertaan, surat berharga, tagihan pada bank lain) ikut dibiayai dari dana modal sendiri bank di samping memperoleh dana-dana dari sumbersumber di luar bank, seperti dana masyarakat, pinjaman (utang), dan lainlain. Dengan kata lain, CAR adalah rasio kinerja bank untuk mengukur kecukupan modal yang dimiliki bank untuk menunjang aktiva yang mengandung atau menghasilkan risiko, misalnya kredit yang diberikan. CAR juga merupakan indikator terhadap kemampuan bank untuk menutupi penurunan aktivanya sebagai akibat dari kerugian-kerugian bank yang disebabkan oleh aktiva yang berisiko.

\section{Biaya Operasional Pendapatan Operasional (BOPO) \\ Dendawijaya

menjelaskan bahwa biaya operasional adalah semua biaya yang berhubungan langsung dengan kegiatan usaha bank seperti biaya tenaga kerja, penyusutan dan sebagainya. Sedangkan pendapatan operasional terdiri atas semua pendapatan yang merupakan hasil dari kegiatan usaha bank.

Rasio Biaya Operasional Pendapatan Operasional (BOPO) juga dapat diartikan sebagai rasio perbandingan antara biaya operasional dan pendapatan operasional. Fungsi dari rasio BOPO adalah untuk mengukur tingkat efisiensi dan kemampuan bank dalam melakukan kegiatan operasionalnya. Hal ini berarti semakin rendah rasio BOPO akan semakin baik karena bank tersebut semakin efisien dalam mengendalikan biaya operasionalnya. Dengan adanya efisiensi biaya maka keuntungan (laba) yang diperoleh bank akan semakin meningkat (Dendawijaya, 2003:121).

\section{Hipotesis}

Berdasarkan rumusan masalah dan tujuan penelitian maka hipotesis dalam penelitian ini dapat dirumuskan sebagai berikut:

1. Non Performing Financing (NPF) secara signifikan berpengaruh 
Nur, et al/Jurnal Ekonomi Syariah Teori dan Terapan Vol. 6 No. 1 Januari 2019: 97-113; DETERMINAN RETURN ON ASSET (ROA) PADA INDUSTRI PERBANKAN SYARIAH DI INDONESIA PERIODE 2010-2018: PENDEKATAN AUTOREGRESSIVE DISTRIBUTED LAG (ARDL)

terhadap Return on Asset (ROA) pada industri perbankan syariah di Indonesia baik itu dalam jangka panjang dan jangka pendek.

2. Capital Adequacy Ratio (CAR) secara signifikan berpengaruh terhadap Return on Asset (ROA) bank syariah di Indonesia baik itu dalam jangka panjang dan jangka pendek.

3. Biaya Operasional Pendapatan Operasional (BOPO) secara signifikan berpengaruh terhadap Return on Asset (ROA) bank syariah di Indonesia baik itu dalam jangka panjang dan jangka pendek.

\section{Studi Literatur}

Terdapat banyak studi penelitian yang membahas tentang pengaruh variabel kinerja keuangan bank syariah terhadap return on asset (roa). Salah satunya adalah penelitian yang dilakukan oleh Zawadi (2014) yang membahas tentang pengaruh variabel size, CAR, NPL, BOPO, likuiditas, inflasi, suku bunga dan GDP terhadap variabel ROA. Penelitian ini menggunakan metode analisis data panel. Hasil penelitian menunjukkan bahwa terdapat pengaruh yang signifikan antara variabel dependen dan independen.

Penelitian lainnya juga dilakukan oleh Athanasoglou (2005) yang meneliti tentang pengaruh variabel CAR, NPL, BOPO, size, produktivitas, kepemilikan, konsentrasi, inflasi dan output siklikal terhadap variabel ROA dan ROE. Penelitian yang dilakukan oleh
Athanasoglou (2005) menggunakan metode analisis data panel. Hasil penelitian menunjukkan bahwa terdapat pengaruh yang signifikan antara variabel CAR, NPL dan BOPO terhadap variabel ROA.

Wasiuzzaman dan Tarmizi (2010) juga melakukan penelitian tentang pengaruh variabel kinerja keuangan bank syariah yaitu BOPO dan NPF terhadap variabel ROA. Penelitian tersebut menggunakan metode ordinary least squares. Hasil penelitian menunjukkan bahwa variabel BOPO dan NPF berpengaruh neatif dan signifikan terhadap variabel ROA.

\section{METODE PENELITIAN}

\section{Pendekatan Penelitian}

Penelitian ini menggunakan pendekatan kuantitatif.Data yang digunakan dalam penelitian ini merupakan data sekunder berupa data time series variabel kinerja keuangan syariah dengan periode penelitian selama tahun 2010-2018. Teknik analisis dan pengolahan data menggunakan metode Autoregressive Distributed Lag (ARDL).

\section{Identifikasi Variabel}

Variabel independenyang digunakan dalam penelitian ini adalah variabel Non Performing Financing (NPF), Capital Adequacy Ratio (CAR) dan Biaya Operasional Pendapatan Operasional (BOPO). Sedangkan variabel dependen (terikat)nya adalah variabel Return on Asset (ROA). 
Nur, et al/Jurnal Ekonomi Syariah Teori dan Terapan Vol. 6 No. 1 Januari 2019: 97-113; DETERMINAN RETURN ON ASSET (ROA) PADA INDUSTRI PERBANKAN SYARIAH DI INDONESIA PERIODE 2010-2018: PENDEKATAN AUTOREGRESSIVE DISTRIBUTED LAG (ARDL)

Definisi Operasional

Variabel-variabel yang digunakan dalam penelitian ini definisi operasionalnya adalah:

1. Return on Asset (ROA)

Dendawijaya

menyatakan bahwa Return on Asset (ROA) adalah rasio yang digunakan untuk mengukur kemampuan manajemen bank dalam memperoleh keuntungan (laba) secara keseluruhan.Rumus menghitung rasio Return on Asset (ROA) adalah sebagai berikut :

ROA $=\frac{\text { LabaBersilh }}{\text { Total Aktiva }} \times 100 \%$

2. Non Performing Financing (NPF)

Kuncoro dan Suhardjono dalam Ismail (2010:218) menyatakan bahwa kredit/pembiayaan bermasalah adalah suatu keadaan dimana nasabah tidak sanggup membayar sebagian atau seluruh kewajibannya kepada bank seperti yang telah diperjanjikan. Rumus menghitung rasio Non Performing Financing (NPF) adalah sebagai berikut :

NPF $=\frac{\text { Pembiayaan Bermasalah }(\text { KL D \& } M)}{\text { Total Dembiaran }} \times$ $100 \%$

3. Capital Adequacy Ratio (CAR)

Dendawijaya

(2003:122) menyatakan bahwa Capital Adequacy Ratio (CAR) adalah rasio kinerja bank untuk mengukur kecukupan modal yang dimiliki bank untuk menunjang aktiva yang mengandung atau menghasilkan risiko, contohnya adalah kredit atau pembiayaan yang diberikan. Rumus menghitung rasio Capital Adequacy ratio (CAR) adalah sebagai berikut :

CAR

$\frac{\text { Modal Bank }}{\text { Aktiva Tertimbang Menurut Risiko (ATMR) }} \times 100$ $\%$

4. Biaya Operasional Pendapatan Operasional (BOPO)

Denda wijaya

(2003:121) menyatakan bahwa rasio Biaya Operasional Pendapatan Operasional (BOPO) dapat diartikan sebagai rasio perbandingan antara biaya operasional dan pendapatan operasional. Fungsi dari rasio BOPO adalah untuk mengukur tingkat efisiensi dan kemampuan bank dalam melakukan kegiatan operasionalnya. Rumus menghitung rasio Biaya Operasional Pendapatan Operasional (BOPO) adalah sebagai berikut :

BOPO $=\frac{\text { Eraya [Gebanjuperasional }}{\text { Pendapatan Operasional }} \times 100 \%$

\section{Jenis dan Sumber Data}

Data yang

digunakandalampenelitianiniadalah data sekunderberupa data time series rasio keuangan bank syariah dengan periode penelitian selama 8 tahun. Data tersebut diperoleh dari Statistik Perbankan Syariah yang diterbitkan oleh Otoritas Jasa Keuangan (OJK). 
Nur, et al/Jurnal Ekonomi Syariah Teori dan Terapan Vol. 6 No. 1 Januari 2019: 97-113; DETERMINAN RETURN ON ASSET (ROA) PADA INDUSTRI PERBANKAN SYARIAH DI INDONESIA PERIODE 2010-2018: PENDEKATAN AUTOREGRESSIVE DISTRIBUTED LAG (ARDL)

\section{Populasi dan Sampel}

Populasi dalam penelitian ini adalah industri perbankan syariah di Indonesia baik itu Bank Umum Syariah (BUS) maupun Unit Usaha Syariah (UUS). Sedangkan sampel dalam penelitian ini adalah data laporan kevangan industri perbankan syariah di Indonesia baik itu BUS maupun UUS yang dipublikasikan secara lengkap yang diperoleh dari Statistik Perbankan Syariah (SPS) yang diterbitkan oleh Otoritas Jasa Kevangan (OJK) dengan periode penelitian dari bulan Januari 2010 sampai dengan bulan Januari 2018 yang berjumlah 97 bulan. Sehingga sampel dalam penelitian ini berjumlah 97 ( $\mathrm{n}=97)$.

\section{Teknik Analisis Data}

Teknik analisis data dalam penelitian ini menggunakan metode Autoregressive Distributed Lag (ARDL) dengan menggunakan software Eviews 9 untuk menguji pengaruh jangka panjang dan jangka pendek antara variabel dependen dengan variabel independen.

Ekananda (2014:90) menyatakan bahwa metode ARDL adalah metode ekonometrika yang mengasumsikan bahwa suatu variabel dipengaruhi oleh variabel itu sendiri tetapi dalam waktu sebelumnya. Dengan meggunakan metode ARDL, dapat dianalisis hubungan jangka panjang ketika variabel penjelasnya bersifat I(0) atau I(1). Metode ARDL tidak hanya bertujuan untuk melihat pengaruh antar variabel seperti metode regresi pada umumnya.
Pesaran et al (1999) menyatakan bahwa metode ARDL sering digunakan dalam ekonometrika karena metode tersebut menguji pengaruh jangka panjang, jangka pendek serta kointegrasi antar variabel. Terdapat beberapa keunggulan dari model ARDL yaitu sebagai berikut :

1. Metode ARDL tidak mementingkan tingkat stasioneritas data, berbeda dengan model VAR dan VECM yang mengharuskan variabel stasioner pada ordo yang sama, meskipun demikian model ARDL tidak bisa digunakan apabila data stasioner dalam bentuk second difference atau I(2).

2. Model ARDL tidak mementingkan variabel terkointegrasi pada ordo yang sama tetapi dalam uji stasioneritas data, variabel harus stasioner pada tingkat level dan first difference. Variabel tidak boleh stasioner pada tingkat second difference.

3. Model ARDL tidak mempermasalahkan jumlah sampel atau observasi yang sedikit. Secara singkat, langkah-langkah yang harus dilakukan dalam analisis data dengan metode Autoregressive Distributed Lag (ARDL) adalah sebagai berikut :

1. Melakukan uji stasioneritas data baik pada tingkat level maupun first difference dengan tujuan untuk memastikan bahwa data yang digunakan tidak ada yang 
Nur, et al/Jurnal Ekonomi Syariah Teori dan Terapan Vol. 6 No. 1 Januari 2019: 97-113; DETERMINAN RETURN ON ASSET (ROA) PADA INDUSTRI PERBANKAN SYARIAH DI INDONESIA PERIODE 2010-2018: PENDEKATAN AUTOREGRESSIVE DISTRIBUTED LAG (ARDL)

I(2) atau stasioner pada tingkat second difference.

2. Menentukan lag maksimum dengan menggunakan metode Akaike Information Criterion (AIC), Schwarz Bayesian Information Criterion ( $S B C$ ) dan Hannan-Quinn Criterion (HQ).

3. Melakukan uji kointegrasi ARDL (Bounds Testing Cointegration) dengan tujuan untuk melihat apakah terdapat hubungan jangka panjang antara variabel dependen dengan variabel independen.

4. Melakukan pengujian model ARDL jangka panjang dengan tujuan untuk melihat koefisien hubungan jangka panjang dari variabel independen terhadap variabel independen.

5. Mengestimasi Error Correction Model (ECM) untuk mengetahui adanya hubungan jangka pendek antar variabel.

\section{HASIL DAN PEMBAHASAN}

\section{Uji Stasioneritas Data (Unit Root Test)}

Penelitian ini menggunakan data sekunder berupa data runtut waktu (time series). Data time series merupakan sekumpulan nilai dari suatu variabel yang diambil pada waktu yang berbeda dan dikumpulkan secara berkala dengan interval waktu tertentu misalnya, harian, bulanan, triwulanan dan sebagainya. Data time series menyimpan banyak permasalahan, salah satunya adalah autokorelasi.
Autokorelasi ini merupakan penyebab data menjadi tidak stasioner. Tidak stasionernya data mengakibatkan kurang baiknya model yang diestimasi. Sekumpulan data dinyatakan stasioner apabila nilai rata-rata dan varian dari data time series tersebut tidak mengalami perubahan secara sistematik sepanjang waktu atau rata-rata dan variannya konstan. Tidak stasionernya data akan mengakibatkan kurang baiknya model yang diestimasi. Pengujian stasioneritas data (unit root test) dapat dilakukan dengan menggunakan metode Augmented Dickey Fuller (ADF) test atau Phillips-Perron (PP) test (Ekananda, 2015:413).

Tahap awal dalam melakukan analisis data penelitian dengan metode ARDL adalah melakukan uji stasioneritas data (unit root test). Tujuan dari melakukan uji stasioneritas data (unit root test) adalah untuk mengetahui dan memastikan bahwa data yang digunakan stasioner baik pada tingkat level maupun first difference. Dalam penelitian ini, uji stasioneritas data yang digunakan adalah menggunakan metode Augmented Dickey Fuller (ADF) test atau dapat disingkat menjadi uji ADF.

Uji ADF bertujuan untuk mengetahui apakah suatu variabel stasioner atau tidak dengan cara melihat nilai probabilitas. Apabila nilai probabilitas lebih kecil dari $a=1 \%, a=5 \%$ dan $a=10 \%$ maka $\mathrm{Hl}$ diterima atau dengan kata lain data time series stasioner pada tingkat level atau first difference. Berikut adalah 
Nur, et al/Jurnal Ekonomi Syariah Teori dan Terapan Vol. 6 No. 1 Januari 2019: 97-113; DETERMINAN RETURN ON ASSET (ROA) PADA INDUSTRI PERBANKAN SYARIAH DI INDONESIA PERIODE 2010-2018: PENDEKATAN AUTOREGRESSIVE DISTRIBUTED LAG (ARDL)

hasil Uji Augmented Dickey Fuller (ADF) pada tingkat level :

\section{Tabel 1.}

Hasil Uji Stasioneritas Data (Level)

\begin{tabular}{|c|c|c|c|c|c|c|}
\hline VAR & T-Stat & Prob & \multicolumn{3}{|c|}{ Critical Valus } & Kat \\
\cline { 4 - 6 } & & & $1 \%$ & $5 \%$ & $10 \%$ & \\
\hline ROA & -2.150275 & 0.2259 & -3.499910 & -2.891871 & -2.583017 & $\begin{array}{c}\text { Tidal: } \\
\text { Stasioner }\end{array}$ \\
& & & & & & \\
\hline NPF & -1.398993 & 0.5798 & -3.499910 & -2.891871 & -2.583017 & $\begin{array}{c}\text { Tidal: } \\
\text { Stasioner }\end{array}$ \\
\hline CAR & -4.249097 & 0.0009 & -3.499910 & -2.891871 & -2.583017 & Stasioner \\
\hline BOPO & -1.060285 & 0.7287 & -3.500669 & -2.892200 & -2.583192 & $\begin{array}{c}\text { Tidal: } \\
\text { Stasioner }\end{array}$ \\
\hline
\end{tabular}

Hasil uji stasioneritas data dengan menggunakan metode Augmented Dickey Fuller (ADF) pada tingkat level menunjukkan bahwa nilai probabilitas dari variabel ROA, NPF dan BOPO lebih besar dari $a=1 \%, a=5 \%$ dan $a=10 \%$, Sedangkan nilai probabilitas dari variabel CAR lebih kecil dari $a=1 \%, a=5 \%$ dan $a=10 \%$. Hal ini menunjukkan bahwa variabel ROA, NPF dan BOPO tidak stasioner pada tingkat level. Sedangkan variabel CAR stasioner pada tingkat level.

Apabila data tidak stasioner pada tingkat level maka harus dilakukan uji stasioneritas data pada tingkat first difference. Uji stasioneritas data pada tingkat first difference juga menggunakan metode Augmented Dickey Fuller (ADF). Berikut adalah hasil Uji Augmented Dickey Fuller (ADF) pada tingkat first difference:
Tabel 2. Hasil Uji Stasioneritas Data (First Difference)

\begin{tabular}{|c|c|c|c|c|c|c|}
\hline \multirow[t]{2}{*}{ VAR } & \multirow[t]{2}{*}{ T-Stat } & \multirow[t]{2}{*}{ Prob } & \multicolumn{3}{|c|}{ Critical Value } & \multirow[t]{2}{*}{ Ket } \\
\hline & & & $1 \%$ & $5 \%$ & $10 \%$ & \\
\hline$\overline{R O A}$ & -10.03881 & 0.0000 & -3.501445 & -2.892536 & -2.583371 & Stasioner \\
\hline NPF & -12.37703 & 0.0001 & -3.500669 & -2.892200 & -2.583192 & Stasioner \\
\hline CAR. & -10.77117 & 0.0000 & -3.501445 & -2.892536 & -2.583371 & Stasioner \\
\hline BOPO & -16.06897 & 0.0001 & -3.500669 & -2.892200 & -2.583192 & Stastioner \\
\hline
\end{tabular}

Hasil uji stasioneritas data dengan menggunakan metode Augmented Dickey Fuller (ADF) pada tingkat first difference menunjukkan bahwa nilai probabilitas dari seluruh variabel lebih kecil dari $a=1 \%, a=5 \%$ dan $a=10 \%$. Hal ini menunjukkan bahwa seluruh variabel telah stasioner pada tingkat first difference. Jadi berdasarkan dari hasil pengujian stasioneritas data pada tingkat first difference tersebut dapat disimpulkan bahwa $\mathrm{HI}$ diterima atau tidak terdapat akar unit/unit root (data time series stasioner).

\section{Uji Penentuan Lag Maksimum}

Untuk menentukan ARDL, peneliti harus menentukan berapa banyak lag yang harus dimasukkan pada model. Terdapat beberapa metode pemilihan model yaitu Akaike Information Criterion (AIC), Schwarz Bayesian Information Criterion (SBC) dan Hannan-Quinn Criterion (HQ). Ekananda (2014:90) menyatakan bahwa besarnya lag yang akan dipilih untuk setiap model ditentukan oleh besarnya nilai Akaike Information Criterion (AIC). Jika besarnya suatu lag memberikan nilai AIC yang paling kecil terhadap model, maka jumlah lag 
Nur, et al/Jurnal Ekonomi Syariah Teori dan Terapan Vol. 6 No. 1 Januari 2019: 97-113; DETERMINAN RETURN ON ASSET (ROA) PADA INDUSTRI PERBANKAN SYARIAH DI INDONESIA PERIODE 2010-2018: PENDEKATAN AUTOREGRESSIVE DISTRIBUTED LAG (ARDL)

tersebut yang akan dipilih. Sedangkan berdasarkan Pesaran et al (2001) menyatakan bahwa dalam menentukan lag maksimum, digunakan pendekatan Akaike Information Criterion (AIC) dan Schwarz Bayesian Information Criterion $(S B C)$. Foster dan Sober dalam Indiharwati (2017) menyatakan bahwa pendekatan AIC memberikan gambaran yang paling dekat terhadap realitas, sedangkan pendekatan SBC dibangun untuk mengidentifikasi model berdasarkan data yang dimiliki dan konsisten secara statistik.

Dalam menentukan ARDL, peneliti harus menentukan berapa banyak lag yang harus dimasukkan pada model. Berikut adalah hasil uji penentuan lag maksimum pada penelitian ini:

Tabel 3. Uji Penentuan Lag Maksimum

\begin{tabular}{|c|c|c|c|c|c|c|}
\hline Log & Logl & LR & FPE & AIC & SC & HQ \\
\hline 0 & -590.0931 & NA & 4.156573 & 12.77620 & 12.88512 & 12.82018 \\
\hline 1 & -404.5890 & 351.0615 & 0.108593 & 9.130946 & $9.675591^{4}$ & 9.3508584 \\
\hline 2 & -383.5819 & 37.94831 & 0.097704 & 9.023267 & 10000363 & 9.419108 \\
\hline 3 & -360.6934 & $39.37802^{4}$ & 0.0846694 & $8.875127^{4}$ & 10.29120 & 9.446899 \\
\hline 4 & -344.8428 & 25.90633 & 0.085731 & 8.878341 & 10.73013 & 9.626042 \\
\hline
\end{tabular}

Berdasarkan hasil uji penentuan lag maksimum diatas, Eviews 9 merekomendasikan panjang lag 3. Hal ini dikarenakan tiga dari kriteria penentuan jumlah lag maksimum yaitu LR, FPE dan AIC menunjukkan tingkat signifikasi pada lag ke 3 atau dapat dikatakan bahwa penentuan jumlah lag maksimum berdasarkan pada jumlah bintang (*) terbanyak dalam suatu lag.

\section{Uji Kointegrasi ARDL}

Tahapselanjutnyaadalahmelakuka nujikointegrasi ARDL atau bounds testing cointegration. Uji kointegrasi ARDL dilakukan dengan tujuan untuk mengetahui apakah terdapat kointegrasi antar variable penelitian atau tidak. Apabila terdapat kointegrasi antar variabel, dapat dikatakan bahwa terdapat hubungan jangka panjang antar variable penelitian.

Kriteria penentuan dari uji kointegrasi ARDL adalah apabila nilai Fstatistic berada dibawah nilai I(0) Bound maka dapat dikatakan bahwa tidak terdapat kointegrasi antar variabel atau tidak terdapat hubungan jangka panjang antar variabel. Sedangkan apabila nilai Fstatistic berada diantara atau diatas nilai I(1) Bound maka dapat dikatakan bahwa terdapat kointegrasi antar variabel atau terdapat hubungan jangka panjang antar variabel. Berikut adalah hasil dari uji kointegrasi ARDL pada penelitian ini:

\section{Tabel 4.}

Uji Kointegrasi ARDL

\begin{tabular}{|c|c|c|}
\hline Test Statistic & Value & $\mathrm{K}$ \\
\hline F-statistic & 2.807490 & 3 \\
\hline \multicolumn{3}{|c|}{ Critical Value Bounds } \\
\hline Significance & $\mathrm{I}(0)$ Bound & $\mathrm{I}(1)$ Bound \\
\hline $10 \%$ & 2.72 & 3.77 \\
\hline $5 \%$ & 3.23 & 4.35 \\
\hline $2.5 \%$ & 3.69 & 4.89 \\
\hline $1 \%$ & 4.29 & 5.61 \\
\hline
\end{tabular}

Berdasarkan dari tabel diatas, dapat dilihat bahwa nilai F-statistic adalah sebesar 2.807490 dan tingkat signifikansi berada di $10 \%$ dengan nilai $1(0)$ Bound sebesar 2.72 dan nilai I(1) Bound sebesar 3.77. Hasil dari uji kointergasi ARDL atau bounds testing cointegration menunjukkan bahwa nilai F-statistic berada diantara 
Nur, et al/Jurnal Ekonomi Syariah Teori dan Terapan Vol. 6 No. 1 Januari 2019: 97-113; DETERMINAN RETURN ON ASSET (ROA) PADA INDUSTRI PERBANKAN SYARIAH DI INDONESIA PERIODE 2010-2018: PENDEKATAN AUTOREGRESSIVE DISTRIBUTED LAG (ARDL)

nilai I(0) Bound dan I(1) Bound. Jadi dapat dikatakan bahwa terdapat kointegrasi antar variabel penelitian dan juga dapat dikatakan bahwa terdapat hubungan jangka panjang antar variabel penelitian.

\section{Uji Estimasi Koefisien Jangka Panjang} dan Jangka Pendek

Tahap terakhir dari teknik analisis data dengan menggunakan metode ARDL adalah melakukan uji estimasi koefisien jangka panjang dan jangka pendek. Ekananda (2014:122) menyatakan bahwa setelah terbukti terdapat hubungan kointegrasi antar variabel, tahap selanjutnya adalah melakukan estimasi koefisien jangka panjang.

Setelah melakukan estimasi koefisien jangka panjang untuk model ARDL, langkah selanjutnya adalah melakukan estimasi error correction model (ECM). Error correction model adalah model ARDL yang telah diperluas dengan error correction term. Error correction term dihitung berdasarkan koefisien jangka panjang yang telah diestimasi (Falianty, 2003).

Hal yang penting dalam melakukan estimasi model ECM adalah error correction term (ECT) harus bernilai negatif, karena nilai negatif dalam ECT menunjukkan bahwa model yang diestimasi adalah valid. Semua koefisien dalam persamaan jangka pendek merupakan koefisien yang menghubungkan model dinamis dalam jangka pendek (Apriyanto, 2016).
Berikut adalah hasil uji estimasi koefisien jangka panjang dalam penelitian ini:

Tabel 5.

Hasil Uji Estimasi Koefisien Jangka Panjang

\begin{tabular}{|c|c|c|}
\hline Variable & Coefficient & Prob \\
\hline NPF & -0.244937 & 0.0620 \\
\hline CAR & 0.027738 & 0.6496 \\
\hline BOPO & -0.036378 & 0.0187 \\
\hline C & 4.948672 & 0.0001 \\
\hline
\end{tabular}

Berdasarkan dari hasil uji estimasi koefisien jangka panjang pada tabel 5 dapat dikatakan bahwa:

1. Variabel Non Performing Financing (NPF) berpengaruh negatif dan signifikan terhadap variabel Return on Asset (ROA) dalam jangka panjang. Hal ini dapat dilihat dari nilai koefisien sebesar -0.244937 yang menunjukkan nilai yang negatif dan probabilitas NPF sebesar 0.0620 yang signifikan pada tingkat $10 \%$. Jadi dapat disimpulkan bahwa meningkatnya rasio ROA akan menyebabkan penurunan dari rasio NPF dan begitupun sebaliknya.

2. Variabel Capital Adequacy Ratio (CAR) berpengaruh positif tetapi tidak signifikan terhadap variabel Return on Asset (ROA) dalam jangka panjang. Nilai koefisien dari variabel CAR adalah sebesar 0.027738 yang menunjukkan bahwa variabel CAR berpengaruh positif terhadap variabel Return on Asset (ROA) akan tetapi 
Nur, et al/Jurnal Ekonomi Syariah Teori dan Terapan Vol. 6 No. 1 Januari 2019: 97-113; DETERMINAN RETURN ON ASSET (ROA) PADA INDUSTRI PERBANKAN SYARIAH DI INDONESIA PERIODE 2010-2018: PENDEKATAN AUTOREGRESSIVE DISTRIBUTED LAG (ARDL)

probabilitas CAR sebesar 0.6496 menunjukkan hasil yang tidak signifikan. Jadi dapat disimpulkan bahwa rasio CAR tidak signifikan dalam mempengaruhi rasio ROA.

3. Variabel Biaya Operasional Pendapatan Operasional (BOPO) berpengaruh negatif dan signifikan terhadap variabel Return on Asset (ROA) dalam jangka panjang. Hasil dari uji estimasi koefisien jangka panjang menunjukkan bahwa nilai koefisien dari variabel BOPO adalah sebesar -0.036378 yang menunjukkan nilai yang negatif dan probabilitas BOPO sebesar 0.0187 yang signifikan pada tingkat 10\%. Jadi dapat disimpulkan bahwa meningkatnya rasio ROA akan menyebabkan penurunan dari rasio BOPO dan begitupun sebaliknya.

Setelah melakukan uji estimasi koefisien jangka panjang untuk model ARDL, langkah selanjutnya adalah melakukan uji estimasi koefisien jangka pendek dengan error correction model (ECM). Hasil yang perlu diperiksa adalah nilai koefisien dari error correction term (ect) atau CointEq(-1) dimana harus bernilai negatif, karena nilai negatif dalam error correction term (ect) atau CointEq(1) menunjukkan bahwa model yang diestimasi adalah valid. Hasil uji estimasi koefisien jangka pendek dalam penelitian ini menunjukkan bahwa :
Tabel 6.

Hasil Uji Estimasi Koefisien Jangka Pendek

\begin{tabular}{|c|c|c|}
\hline Variable & Coefficient & Prob \\
\hline D(NPF) & -0.093099 & 0.0736 \\
\hline D(CAR) & 0.002238 & 0.9351 \\
\hline D(CAR(-1)) & -0.112542 & 0.0005 \\
\hline D(CAR(-2)) & 0.045402 & 0.0933 \\
\hline D(BOPO) & -0.013827 & 0.0457 \\
\hline CointEq(-1) & -0.380095 & 0.0000 \\
\hline
\end{tabular}

Hasil dari uji estimasi koefisien jangka pendek pada tabel 6 menunjukkan bahwa:

1. Nilai koefisien dari variabel ect(-1) atau CointEq(-1) adalah sebesar 0.380095 yang menunjukkan nilai yang negatif dengan probabilitas sebesar 0.0000 dan signifikan.

2. Variabel Non Performing Financing (NPF) berpengaruh negatif dan signifikan terhadap variabel Return on Asset (ROA) dalam jangka pendek. Hal ini dapat dilihat dari nilai koefisien sebesar -0.093099 yang menunjukkan nilai yang negatif dan probabilitas NPF sebesar 0.0736 yang signifikan pada tingkat $10 \%$. Jadi dapat disimpulkan bahwa meningkatnya rasio ROA akan menyebabkan penurunan dari rasio NPF dan begitupun sebaliknya.

3. Variabel Capital Adequacy Ratio (CAR) berpengaruh positif dan signifikan terhadap variabel Return on Asset (ROA) dalam jangka pendek. Hal ini dapat dilihat dari nilai koefisien sebesar 0.045402 dan probabilitas CAR sebesar 0.0933 
Nur, et al/Jurnal Ekonomi Syariah Teori dan Terapan Vol. 6 No. 1 Januari 2019: 97-113; DETERMINAN RETURN ON ASSET (ROA) PADA INDUSTRI PERBANKAN SYARIAH DI INDONESIA PERIODE 2010-2018: PENDEKATAN AUTOREGRESSIVE DISTRIBUTED LAG (ARDL)

menunjukkan hasil yang signifikan pada tingkat $10 \%$. Jadi dapat disimpulkan bahwa meningkatnya rasio ROA akan menyebabkan kenaikan dari rasio CAR dan begitupun sebaliknya.

4. Variabel Biaya Operasional Pendapatan Operasional (BOPO) berpengaruh negatif dan signifikan terhadap variabel Return on Asset (ROA) dalam jangka pendek. Hal ini dapat dilihat dari nilai koefisien sebesar $\quad-0.013827 \quad$ yang menunjukkan nilai yang negatif dan probabilitas BOPO sebesar 0.0457 yang signifikan pada tingkat 10\%. Jadi dapat disimpulkan bahwa meningkatnya rasio ROA akan menyebabkan penurunan dari rasio BOPO dan begitupun sebaliknya.

\section{Hasil Analisis Penelitian}

Variabel Non Performing Financing (NPF) berpengaruh negatif dan signifikan terhadap variabel Return on Asset (ROA) pada industri perbankan syariah di Indonesia baik dalam jangka panjang maupun jangka pendek. Hasil penelitian menunjukkan bahwa nilai koefisien dari variabel NPF adalah sebesar -0.244937 yang menunjukkan nilai yang negatif dan probabilitas NPF sebesar 0.0620 yang signifikan pada tingkat 10\%. Dan dalam jangka pendek, hasil penelitian menunjukkan bahwa nilai koefisien dari variabel NPF adalah sebesar -0.093099 yang menunjukkan nilai yang negatif dan probabilitas NPF sebesar 0.0736 yang signifikan pada tingkat $10 \%$.

Hasil penelitian tersebut didukung oleh penelitian sebelumnya yang dilakukan oleh Wasiuzzaman dan Tarmizi (2010) yang menyatakan bahwa variabel NPF berpengaruh negatif dan signifikan terhadap ROA. Wasiuzzaman dan Tarmizi (2010) menyatakan bahwa tingginya rasio NPF dapat menyebabkan rasio ROA menjadi menurun. Hubungan negatif antara NPF dan ROA menunjukkan bahwa bank syariah harus lebih fokus terhadap risiko kreditnya dikarenakan risiko kredit merupakan salah satu faktor yang menyebabkan penurunan dari laba bank syariah.

Variabel Capital Adequacy Ratio (CAR) berpengaruh positif dan tidak signifikan terhadap variabel Return on Asset (ROA) pada industri perbankan syariah di Indonesia pada jangka panjang. Sedangkan dalam jangka pendek, variabel Capital Adequacy Ratio (CAR) berpengaruh positif dan signifikan terhadap variabel Return on Asset (ROA) pada industri perbankan syariah di Indonesia. Hasil penelitian menunjukkan bahwa nilai koefisien dari variabel CAR adalah sebesar 0.027738 yang menunjukkan nilai yang positif dan probabilitas CAR sebesar 0.6496 menunjukkan hasil yang tidak signifikan dalam jangka panjang. Sedangkan dalam jangka pendek, variabel CAR berpengaruh positif dan signifikan. Hasil penelitian menunjukkan bahwa variabel Capital Adequacy Ratio (CAR) 
Nur, et al/Jurnal Ekonomi Syariah Teori dan Terapan Vol. 6 No. 1 Januari 2019: 97-113; DETERMINAN RETURN ON ASSET (ROA) PADA INDUSTRI PERBANKAN SYARIAH DI INDONESIA PERIODE 2010-2018: PENDEKATAN AUTOREGRESSIVE DISTRIBUTED LAG (ARDL)

berpengaruh positif dengan nilai koefisien sebesar 0.045402 dan probabilitas CAR adalah sebesar 0.0933 yang menunjukkan hasil yang signifikan pada tingkat $10 \%$.

Hasil penelitian didukung oleh penelitian yang Athanasoglou (2005) juga menyatakan bahwa variabel CAR berpengaruh positif dan signifikan terhadap ROA. Hal ini mencerminkan kondisi keuangan yang sehat karena bank dengan rasio kecukupan modal yang tinggi dapat meningkatkan peluang bisnis yang lebih tinggi dan lebih efektif. Selain itu, rasio kecukupan modal yang tinggi juga dapat menyebabkan bank menjadi lebih fleksibel dalam menangani masalah yang timbul akibat dari risiko kredit atau kerugian yang tidak terduga sehingga dapat meningkatkan rasio profitabilitas atau dalam penelitian ini dapat diproksikan dengan rasio ROA.

Variabel Biaya Operasional Pendapatan Operasional (BOPO) berpengaruh negatif dan signifikan terhadap variabel Return on Asset (ROA) pada industri perbankan syariah di Indonesia baik dalam jangka panjang maupun jangka pendek. Hasil penelitian dalam jangka panjang menunjukkan bahwa nilai koefisien adalah sebesar 0.036378 yang menunjukkan nilai yang negatif dan probabilitas BOPO sebesar 0.0187 yang signifikan pada tingkat $10 \%$. Sedangkan dalam jangka pendek, hasil penelitian menunjukkan bahwa nilai koefisien adalah sebesar -0.013827 yang menunjukkan nilai yang negatif dan probabilitas BOPO sebesar 0.0457 yang signifikan pada tingkat $10 \%$.

Hasil penelitian tersebut didukung oleh penelitian yang dilakukan oleh Zawadi (2014) yang menyatakan bahwa variabel BOPO berpengaruh negatif dan signifikan terhadap ROA. Zawadi (2014) menyatakan bahwa pengendalian biaya operasional adalah salah satu syarat agar rasio ROA yang diperoleh bank tinggi. Oleh karena itu, pengendalian biaya operasional merupakan rasio yang sangat penting dalam meningkatkan profitabilitas bank.

\section{KESIMPULAN}

Berdasarkan hasil dan pembahasan yang telah dijelaskan mengenai faktor-faktor yang mempengaruhi variabel Return on Asset (ROA) yaitu Non Performing Financing (NPF), Capital Adequacy Ratio (CAR) dan Biaya Operasional Pendapatan Operasional (BOPO) pada industri perbankan syariah di Indonesia periode 2010-2018, maka hasil penelitian dapat disimpulkan sebagai berikut :

1. Berdasarkan pada analisis data yang telah dilakukan dengan menggunakan metode ARDL, dapat disimpulkan bahwa variabel Non Performing Financing (NPF) berpengaruh negatif dan signifikan terhadap variabel Return on Asset (ROA) pada industri perbankan syariah di Indonesia baik dalam jangka panjang maupun jangka pendek. 
Nur, et al/Jurnal Ekonomi Syariah Teori dan Terapan Vol. 6 No. 1 Januari 2019: 97-113; DETERMINAN RETURN ON ASSET (ROA) PADA INDUSTRI PERBANKAN SYARIAH DI INDONESIA PERIODE 2010-2018: PENDEKATAN AUTOREGRESSIVE DISTRIBUTED LAG (ARDL)

2. Berdasarkan pada analisis data yang telah dilakukan dengan menggunakan metode ARDL, dapat disimpulkan bahwa variabel Capital Adequacy Ratio (CAR) berpengaruh positif akan tetapi tidak signifikan terhadap variabel Return on Asset (ROA) pada industri perbankan syariah di Indonesia baik dalam jangka panjang. Sedangkan dalam jangka pendek, variabel Capital Adequacy Ratio (CAR) berpengaruh positif dan signifikan terhadap variabel Return on Asset (ROA) pada industri perbankan syariah di Indonesia.

3. Berdasarkan pada analisis data yang telah dilakukan dengan menggunakan metode ARDL, dapat disimpulkan bahwa variabel Biaya Operasional Pendapatan Operasional (BOPO) berpengaruh negatif dan signifikan terhadap variabel Return on Asset (ROA) pada industri perbankan syariah di Indonesia baik dalam jangka panjang maupun jangka pendek.

\section{DAFTAR PUSTAKA}

Arifin, Zainul. 2002. Dasar-Dasar Manajemen Bank Syariah. Bandung: Alfabeta.

Athanasoglou, Panayiotis, et al. 2005. Bank-Specific, Industry-Specific and

Macroeconomic Determinants of Bank Profitability. MPRA Paper No. 32026, 4-35.

Dendawijaya, Lukman. 2003. Manajemen Perbankan. Jakarta: Ghalia Indonesia.

Ekananda, Mahyus. 2014. Analisis Data Time Series: untuk Penelitian Ekonomi, Manajemen dan Akuntansi. Jakarta: Mitra Wacana Media.

Ekananda, Mahyus. 2015. Ekonometrika Dasar: untuk Penelitian Ekonomi, Sosial dan Bisnis. Jakarta: Mitra Wacana Media.

Haron, Sudin. 2004. Determinant of Islamic Bank Profitability. Working Paper Series No. 002, Global Journal of Finance and Economics, 1 (1), 1-22.

Ilsmail. 2011. Perbankan Syariah. Jakarta: Kencana Prenada Media.

Kasmir. 2013. Analisis Laporan Keuangan. Jakarta: PT Raja Grafindo Persada.

Muhamad. 2002. Manajemen Bank Syariah. Yogyakarta: UPP AMP YKPN.

Pesaran, M. Hashem, et al. 1999. Bounds Testing Approaches to the Analysis of Level Relationships. Journal of Applied Econometrics, (16), 289326.

Pesaran, M. Hashem, et al. 2001. Bounds Testing Approaches to the Analysis of Long Run Relationships. Trinity College, Cambridge.

Ramlall, I. 2009. Bank-Specific, IndustrySpecific and Macroeconomic Determinants of Profitability in 
Nur, et al/Jurnal Ekonomi Syariah Teori dan Terapan Vol. 6 No. 1 Januari 2019: 97-113; DeterminAN RETURN ON ASSET (ROA) PADA INDUSTRI PERBANKAN SYARIAH DI INDONESIA PERIODE 2010-2018: PENDEKATAN AUTOREGRESSIVE DISTRIBUTED LAG (ARDL)

Taiwanese Banking System: Under

Panel Data Estimation.

International Research Journal of Finance and Economics, (34), 160167.

Umam, Khotibul. 2016. Perbankan Syariah:

Dasar-Dasar dan Dinamika Perkembangannya di Indonesia. Jakarta: PT Raja Grafindo Persada.

Usman, Rachmadi. 2012. Aspek Hukum Perbankan Syariah. Jakarta: Sinar Grafika.

Wasiuzzaman, Shaista and Hanimas Ayu B† Ahmad Tarmizi. 2014. Profitability of Islamic Banks in Malaysia: An Empirical Analysis. Journal of Islamic Economics, Banking and Finance, 6(4), 53-68.

Zawadi, Ally. 2014. Determinants of Banks Profitability in a Developing Economy: Empirical Evidence from Tanzania. European Journal of Business and Management, 6(31), 363-375. 